\title{
High-throughput screens to identify novel interactions between erythrocyte multi-pass receptors and $P$. falciparum merozoite surface ligands that are involved in invasion
}

\author{
Madushi Wanaguru*, Cecile Wright-Crosnier, Leyla Bustamante, Brian McDade, Julian Rayner, Gavin J Wright
}

From Parasite to Prevention: Advances in the understanding of malaria

Edinburgh, UK. 20-22 October 2010

Invasion of erythrocytes by $P$. falciparum merozoites is a complex multistep process involving a series of molecular recognition events between parasite ligands and their receptors on the erythrocyte surface. Although many potential $P$. falciparum invasion ligands are known, the erythrocyte receptors they interact with have been identified only for a handful of cases. Studying extracellular binding events between membrane-embedded proteins in vitro is challenging and beyond the reach of standard approaches such as co-immunoprecipitation and yeast two-hybrid screens. These interactions are generally of very low affinity and often require specific motifs generated via post-translational processing; furthermore, amphipathic membrane-spanning proteins are difficult to manipulate biochemically. The Duffy Antigen Receptor for Chemokines (DARC), a multi-pass G-protein coupled erythrocyte receptor is known to be important for invasion by $P$. vivax but no multi-pass receptor has been established to play a role in $P$. falciparum invasion. With the aim of identifying such a receptor, we have developed a flow cytometry based, high-throughput strategy that can detect transient, extracellular protein: protein interactions. We are in the process of screening the soluble, recombinant ectodomains of $39 \mathrm{P}$. falciparum merozoite surface proteins against an expression library of 45 erythrocyte multi-pass surface proteins. We will present our screening strategy and preliminary results.

Published: 20 October 2010

The Wellcome Trust Sanger Institute, Wellcome Trust Genome Campus, Hinxton, Cambridge, CB10 1SA, UK
doi:10.1186/1475-2875-9-S2-P57

Cite this article as: Wanaguru et al:: High-throughput screens to identify novel interactions between erythrocyte multi-pass receptors and $P$. falciparum merozoite surface ligands that are involved in invasion. Malaria Journal 2010 9(Suppl 2):P57.
Submit your next manuscript to BioMed Central and take full advantage of:

- Convenient online submission

- Thorough peer review

- No space constraints or color figure charges

- Immediate publication on acceptance

- Inclusion in PubMed, CAS, Scopus and Google Scholar

- Research which is freely available for redistribution 